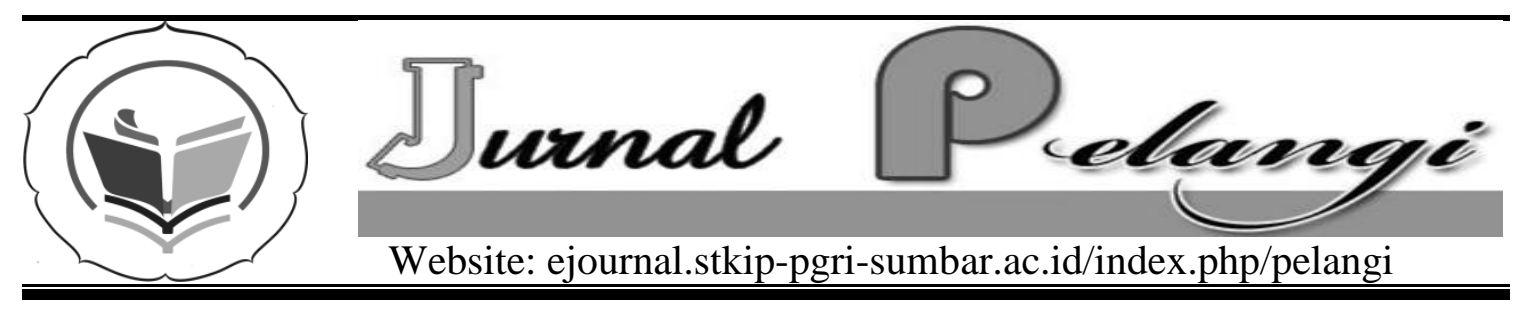

\title{
PENERAPAN MODEL ACTIVE KNOWLEDGE SHARING PADA PEMBELAJARAN MATEMATIKA DI KELAS V SDN 10 SUNGAI SAPIH KOTA PADANG
}

\author{
Hendrizal $^{1)}$, Muhiddinur Kamal ${ }^{2)}$, Asrina Mulyati ${ }^{3)}$ \\ STKIP ADZKIA Padang \\ hendrizal76@yahoo.com
}

INFO ARTIKEL

Diterima: 31 Maret 2015

Disetujui: 22 Juni 2015

Kata Kunci:

Model AKS,

Pembelajaran

Matematika
Abstrak

Siswa belajar matematika karena takut pada guru bukan atas dorongan keingintahuannya. Sehingga siswa hanya berorentasi pada hasil akhir, bukan pada prosesnya. Agar siswa tertarik mengikuti pembelajaran matematika, maka seharusnya pembelajaran matematika dilaksanakan dengan cara yang menarik, menyenangkan, dan melibatkan siswa secara aktif. Masalah ini jika dibiarkan berlanjut akan berakibat pada hasil belajar yang diperoleh siswa di bawah KKM ( $\leq 75)$. Salah satu cara yang dapat dilakukan oleh guru adalah menerapan Model AKS pada pembelajaran Matematika Kelas V SDN 10 Sungai Sapih kota Padang. Rumusan masalah dari penelitian ini adalah "apakah hasil belajar matematika siswa yang mengikuti model pembelajaran AKS lebih baik dari pada hasil belajar matematika siswa yang mengikuti model pembelajaran konvensional?". Penelitian ini termasuk penelitian eksperimen dengan rancangan penelitian adalah Randomized Control Group Only Design. Populasi penelitian ini adalah siswa kelas $V$ yang terdaftar pada tahun ajaran 2014/2015 sebanyak empat kelas (161 orang). Dengan teknik pengambilan sampel dengan cara pengundian nomor, diperoleh kelas V.c sebagai kelas eksperimen dan kelas V.d sebagai kelas kontrol. Pengolahan data hasil tes akhir dilakukan melalui uji hipotesis yang menggunakan uji-t. Setelah dilakukan perhitungan diperoleh $t_{\text {hitung }}>t_{\text {tabel }}(2,915>$ 1,66), hal ini menunjukkan bahwa hipotesis yang diajukan diterima. Artinya hasil belajar siswa yang mengikuti pembelajaran dengan model AKS lebih baik dari pada hasil belajar matematika siswa yang mengikuti pembelajaran dengan model konvensional. 


\section{Abstract}

Keywords:

AKS Model, Learning Mathematics

\section{PENDAHULUAN}

Demi terwujudnya cita-cita bangsa dalam mempersiapkan manusia Indonesia yang berkualitas khususnya pada jenjang pendidikan dasar. Untuk itu, guru sebagai sosok yang berperan penting dan juga sebagai penyedia informasi untuk pengembangan potensi siswa dalam pengelolaan keragaman situasi pembelajaran. Banyak kendala dan tantangan yang dihadapi dan mesti ditanggulangi oleh guru. Khusus untuk meningkatkan kualitas pembelajaran, guru sudah saatnya memberikan perhatian yang lebih besar terhadap model pembelajaran yang digunakan.
Selama ini model pembelajaran yang digunakan masih bersifat konvensional, yang mengacu kepada upaya-upaya menyelesaikan materi hanya dengan menggunakan pendekatan duduk, dengar, catat. Hal ini tidaklah mampu untuk mengembangkan potensi siswa yang ada.

Dalam proses pembelajaran, para guru selalu dituntut untuk berupaya menciptakan iklim kelas yang nyaman serta menyenangkan siswa. Materi yang diberikan betul-betul mempunyai makna secara praktis yang dapat berguna untuk kehidupannya. Tetapi pada kenyataannya, masih banyak sekolah yang 
berorentasi pada hasil akhir evaluasi/ orentasi nilai akhir dengan mengabaikan proses. Sehingga lembaga itu berupaya penuh untuk membantu para siswa dalam menjawab soal evaluasi akhir. Memberikan kemudahan-kemudahan dalam proses pendidikan dengan mengesampingkan hakekat pendidikan itu sendiri, seperti remedial dapat diganti dengan barang atau membeli sesuatu yang tidak ada nilai tambah pada penguasaan ilmu siswa, memaksa/ memarahi, dan menghukum siswa dengan tidak dimengerti alasannya. Hal tersebut dapat menyebabkan para siswa belajar karena takut pada guru bukan atas dorongan keingintahuannya. Sehingga bukan hal yang mustahil siswa hanya berorentasi pada hasil akhir, bukan pada prosesnya yang diutamakan.

Sebagai akibat dari pembelajaran yang kurang berorientasi pada proses maka munculah mental-mental para siswa untuk melakukan perbuatan yang tidak terpuji dan melanggar norma dengan melakukan perbuatan yang menghalalkan segala cara untuk mendapatkan nilai. Sehingga tidak jarang terdengar jual beli nilai ataupun pembocoran soal ujian. Perbuatan jalan pintas untuk mendapatkan nilai di atas sangat berdampak terhadap kemampuan siswa nantinya setelah mereka menamatkan suatu jenjang pendidikan.

Sedangkan akibat jangka panjang dari pembelajaran yang hanya berorientasi pada nilai di atas adalah munculnya para lulusan yang tidak siap pakai dan kurang mampu untuk berkarya sebagai akibat dari kurangnya proses selama dalam pendidikan. Selanjutnya akan muncul generasi-generasi yang tidak kreatif dan kurang tanggap membaca peluang apalagi untuk menciptakan lapangan kerja. Hal di atas sesuai dengan yang dikemukakan oleh Koentjaraningrat (2005: 45-49), yang menjelaskan bahwa, "Kelemahan mentalitas bangsa Indonesia setelah revolusi adalah sikap mental yang merendahkan mutu dan sudah hampir hilang kebutuhan akan kualitas dari hasil karya serta hilangnya rasa peka terhadap mutu". Koentjaraningrat menjelaskan kelemahan mentalitas pasca revolusi antara lain berupa munculnya mentalitas yang suka menerabas, mentalitas yang bernafsu untuk mencapai tujuan secepatcepatnya tanpa banyak melakukan kerelaan berusaha, pengorbanan, usaha yang bertahap selangkah demi selangkah, semua itu sebagai akumulasi dari akibat mentalitas merendahkan mutu.

Adapun akibat jangka pendek dari pelaksanaan pendidikan yang hanya berorientasi pada hasil adalah rendahnya minat dan motivasi siswa untuk melakukan proses belajar. Siswa kurang berminat dengan materi pelajaran. Indikasi ini terlihat dengan rendahnya usaha siswa dalam berbagai kegiatan dalam kelas maupun kegiatan belajar diluar kelas seperti pekerjaan rumah (PR) atau usaha yang rendah dalam mengikuti ujian. Siswa juga menjadi agresif dalam mengganggu siswa lain, dan dengan mudahnya meninggalkan kelas dan semuanya bermuara pada pelanggaran aturan sekolah.

Perilaku-perilaku negatif di atas sebenarnya dapat ditanggulangi jika guru dapat memotivasi belajar siswa dengan model pembelajaran yang menyenang- 
kan dan membuat tantangan-tantangan dalam proses belajar. Jika motivasi sudah tumbuh dalam diri siswa, mereka akan berpartisipasi dalam berbagai kegiatan pembelajaran. Kreatifitas guru dalam melaksanakan berbagai model dalam pembelajaran sebagai modal yang sangat berharga dalam memotivasi siswa dalam belajar sehingga dapat meningkatkan prestasi belajar.

Sekolah Dasar (SD) merupakan sekolah yang sangat mendasari para siswa untuk melanjutkan ke jenjang lebih tinggi. Pendidikan dasar bertujuan memberikan bekal kemampuan dasar kepada siswa untuk mengembangkan kehidupan sebagai pribadi, anggota masyarakat, warga negara dan anggota umat manusia serta mempersiapkan siswa untuk mengikuti pendidikan menengah. Depdikbud (1993: 16).

Keseriusan para guru di tingkat dasar sangat menentukan keberhasilan belajar siswa di tingkat berikutnya. Hal ini beralasan karena pendidikan di tingkat dasar, merupakan modal dasar bagi siswa untuk dapat/ mampu mengembangkan pengetahuan ke arah lebih luas dan mendalam tentang apa yang dipelajarinya.

Matematika merupakan ibu atau ratunya ilmu (Erman Suherman, 2001: 25). Maksudnya matematika adalah ilmu pengetahuan yang membantu ilmu pengetahuan lainnya, seperti Fisika, Kimia, Ekonomi dan lain-lainnya. Untuk itu matematika seharusya dapat dipelajari dengan senang hati tanpa paksaan, dengan demikian dapat mewujutkan tujuan dari pembelajaran matematika itu sendiri.
Matematika adalah salah satu disiplin ilmu yang berpengaruh dan mempunyai peranan penting dalam perkembangan ilmu pengetahuan, teknologi dan memajukan daya pikir manusia. Hal ini sesuai dengan pendapat Erman Suherman, dkk yang menyatakankan bahwa: "Para pelajar memerlukan matematika untuk memenuhi kebutuhan praktis dan memecahkan masalah dalam kehidupan sehari-hari, misalnya dapat berhitung, menghitung isi dan berat, mengumpulkan, mengolah, menyajikan dan menafsirkan data, dapat menggunakan kalkulator dan komputer. Selain itu agar siswa mampu mengikuti pelajaran matematika lebih lanjut, untuk membantu memahami bidang studi lain, dan agar para siswa dapat berpikir logis, kritis, dan praktis, serta bersikap positif dan berjiwa kreatif "(Erman Suherman, 2001: 60).

Berdasarkan uraian di atas dapat disimpulkan bahwa mata pelajaran matematika diberikan pada setiap jenjang pendidikan. Oleh karena itu, matematika memegang peranan penting dalam kehidupan.

Menyadari pentingnya matematika dalam kehidupan, seharus-nya mata pelajaran matematika merupakan mata pelajaran yang menarik dan menyenangkan. Agar siswa tertarik mengikuti pelajaran matematika, maka seharusnya pelajaran matematika dilaksanakan dengan cara yang menarik, menyenangkan, dan melibatkan siswa secara aktif. Hal ini sejalan dengan pendapat Oemar Hamalik yang menjelaskan bahwa guru dan siswa senantiasa dituntut agar menciptakan 
suasana lingkungan belajar yang baik dan menyenangkan, menantang dan menggairahkan. Selain itu, dijelaskan kembali oleh Oemar Hamalik yang menyatakan bahwa: "Kondisi subjek belajar turut menentukan kegiatan dan keberhasilan belajar.

Siswa dapat belajar secara efektif dan efisien apabila berbadan sehat, memiliki intelegensi yang memadai, sikap untuk melakukan kegiatan belajar, memiliki bakat khusus, dan pengalaman yang bertalian dengan pelajaran, serta memiliki minat untuk belajar. (Oemar Hamalik, 2008: 52). Oleh karena itu, pembelajaran hendaknya dilakukan dengan memperhatikan kondisi setiap siswa, sebab siswalah yang akan belajar. Keterlibatan siswa dalam kegiatan pembelajaran dan pelaksanaan pembelajaran dengan memperhatikan kondisi setiap siswa diharapkan dapat meningkatkan hasil belajar siswa. Hasil belajar siswa yang meningkat diharapkan juga dapat meningkatkan kualitas pendidikan.

Pemerintah sudah berupaya dalam meningkatkan kualitas pendidikan. Upaya tersebut diantaranya adalah melakukan perubahan kurikulum, yakni pemerintah menerapkan Kurikulum Tingkat Satuan Pendidikan (KTSP) dalam pelaksanaan pendidikan di Indonesia. Pemerintah mengadakan pelatihan dan sertifikasi terhadap guruguru guna meningkatkan kualitas guru. Pemerintah berupaya menyediakan buku-buku pelajaran guna menunjang proses pembelajaran.

Berdasarkan observasi yang dilakukan di SDN 10 Sungai Sapih Kota
Padang, pembelajaran masih didominasi oleh guru sehingga siswa kurang aktif selama pembelajaran berlangsung. Penulis melihat guru menjelaskan materi secara klasikal, guru menjelaskan materi dengan disertai contoh, kemudian memberi latihan kepada siswa secara individu. Kegiatan siswa adalah mendengar dan membuat catatan, serta mengerjakan latihan yang diberikan oleh guru. Permasalahan di atas menyebabkan rendahnya hasil belajar siswa kelas $\mathrm{V}$ SDN 10 Sungai Sapih. Hal tersebut dapat dilihat dari nilai Ulangan Harian I Matematika Siswa Kelas V SDN 10 Sungai Sapih Kota Padang semester 1 tahun ajaran 2014/2015.

Nilai Ulangan Harian I Matematika Siswa Kelas V SDN 10 Sungai Sapih Kota Padang semester 1 tahun ajaran 2014/2015 disajikan pada Tabel 1. Pada tabel 1 dapat dilihat persentase ketuntasan siswa berada di bawah Kriteria Ketuntasan Minimal (KKM) yang ditetapkan sekolah yakni 75. Untuk mengatasi masalah di atas perlu diadakan upaya pembaharuan dalam pembelajaran matematika. Pembelajaran yang dilaksanakan harus dapat menarik siswa untuk aktif dan terlibat secara mental sehingga minat dan motivasi belajar siswa menjadi lebih baik.

Melalui penggunaan model pembelajaran $A K S$ ini diharapkan siswa mampu memberikan pertanyaan dan membagi pengetahuan matematika yang dimilikinya kepada orang lain. Sehingga dapat meningkatkan hasil belajar matematika siswa. 
Tabel 1. Persentase Ketuntasan Nilai UH I Matematika Siswa Kelas V SDN 10 Sungai Sapih Kota Padang Semester 1 Tahun Ajaran 2014/2015

\begin{tabular}{cccc}
\hline \multirow{2}{*}{ Kelas } & \multirow{2}{*}{ Jumlah Siswa } & \multicolumn{2}{c}{ Persentase Ketuntasan } \\
\cline { 3 - 4 } & & Tuntas & Tidak Tuntas \\
\hline V.a & 40 & 23 & 77 \\
V.b & 40 & 30 & 70 \\
V.c & 40 & 50 & 50 \\
V.d & 41 & 65 & 35 \\
\hline
\end{tabular}

(Sumber: Tata Usaha SDN 10 Sungai Sapih Tahun Ajaran 2014/2015).

Salah satu model pembelajaran aktif yang dapat mengaktifkan siswa adalah model pembelajaran Active Knowledge Sharing (AKS). Model pembelajaran $A K S$ adalah cara mengajar yang bagus untuk menarik perhatian siswa dengan cara berbagi pengetahuan secara aktif (Silberman: 2011). Sehingga penguasaan siswa terhadap materi akan lebih maksimal.

\section{METODOLOGI PENELITIAN}

Jenis penelitian ini adalah penelitian eksperimen. Rancangan yang digunakan dalam penelitian ini adalah The Static Group Comparizon: Randomized Control Group Only Design (Sugiyono: 2009), Populasi dalam penelitian ini adalah seluruh siswa kelas V SDN 10 Sungai Sapih yaitu 161 siswa, sedangkan sampel ada 2 kelas yaitu kelas eksperimen (Vd) dan kelas kontrol (Vd). Dalam penelitian ini peneliti menggunakan software SPSS untuk pengolahan data.

Sumber data dalam penelitian ini adalah seluruh siswa kelas sampel, guru bidang studi matematika kelas $\mathrm{V}$ dan kantor tata usaha SD Negeri 10 Sungai Sapih kota Padang. Secara umum prosedur penelitian terdiri dari 3 tahap, yaitu: tahap persiapan, tahap pelaksanaan, dan tahap akhir. Setelah dilaksanakan tes hasil belajar, diperoleh data tentang hasil belajar matematika siswa. Tes hasil belajar ini diikuti oleh 40 siswa dari kelas eksperimen dan 41 siswa dari kelas kontrol.

\section{HASIL DAN PEMBAHASAN}

Berdasarkan hasil deskripsi dan analisis data tes hasil belajar siswa yang disajikan pada Tabel 2, terlihat bahwa hasil belajar matematika siswa kelas eksperimen lebih tinggi dari pada hasil belajar siswa kelas kontrol. Hal ini dapat dilihat dari nilai rata-rata siswa kelas eksperimen lebih tinggi dari nilai ratarata siswa kelas kontrol. Nilai rata-rata siswa kelas eksperimen adalah 77 sedangkan nilai rata-rata siswa kelas kontrol adalah 67.

Tabel 2. Hasil Perhitungan Data Hasil Belajar

\begin{tabular}{lccccc}
\hline \multicolumn{1}{r}{ Kelas } & $\overline{\mathrm{X}}$ & $\mathrm{N}$ & $\mathrm{S}$ & $\mathrm{X}_{\max }$ & $\mathrm{X}_{\min }$ \\
\hline Eksperimen & 77 & 40 & 16 & 100 & 47 \\
Kontrol & 67 & 41 & 15 & 90 & 40 \\
\hline
\end{tabular}


Tabel 3. Persentase Ketuntasan Siswa pada Kelas Eksperimen dan Kelas Kontrol

\begin{tabular}{lccccc}
\hline \multirow{2}{*}{ Kelas } & Jumlah & \multicolumn{2}{c}{ Tuntas $(\geq 75)$} & \multicolumn{2}{c}{ Tidak Tuntas $(<75)$} \\
\cline { 3 - 6 } & siswa & Jumlah & $\%$ & Jumlah & $\%$ \\
\hline Ekperimen & 40 & 25 & 62,5 & 15 & 37,5 \\
Kontrol & 41 & 19 & 46,3 & 22 & 53,7 \\
\hline
\end{tabular}

Berdasarkan Tabel 2, terlihat bahwa terdapat perbedaan nilai rata-rata antara kelas eksperimen dan kelas kontrol. Rata-rata yang diperoleh kelas eksperimen adalah 77, sedangkan kelas kontrol mempunyai rata-rata 67. Jadi, rata-rata pada kelas eksperimen lebih tinggi dari pada kelas kontrol.

Dilihat dari Kriteria Ketuntasan Minimal (KKM) yang telah ditetapkan, maka kelas eksperimen memiliki jumlah persentase ketuntasan sebesar $62,5 \%$ dan kelas kontrol sebesar 46,3\%. Jadi dapat disimpulkan bahwa persentase jumlah siswa kelas eksperimen lebih tinggi dari pada kelas kontrol. Selain itu, jumlah ketuntasan siswa di kelas eksperimen lebih banyak dari pada kelas kontrol. Hal ini dapat dilihat pada Tabel 3.

Berdasarkan Tabel 3, terlihat bahwa persentase ketuntasan siswa kelas eksperimen lebih tinggi dari pada persentase ketuntasan siswa kelas kontrol. Pada kelas eksperimen, jumlah siswa yang tuntas ada 25 siswa atau $62,5 \%$ dan yang tidak tuntas ada 15 siswa atau $37,5 \%$ dari jumlah keseluruhan siswa kelas eksperimen yaitu 40 siswa. Sedangkan, pada kelas kontrol jumlah siswa yang tuntas ada 19 siswa atau $46,3 \%$ dan yang tidak tuntas 22 siswa atau $53,7 \%$ dari 41 siswa. Persentase ketuntasan kelas sampel disajikan dalam bentuk diagram pada Gambar 1.

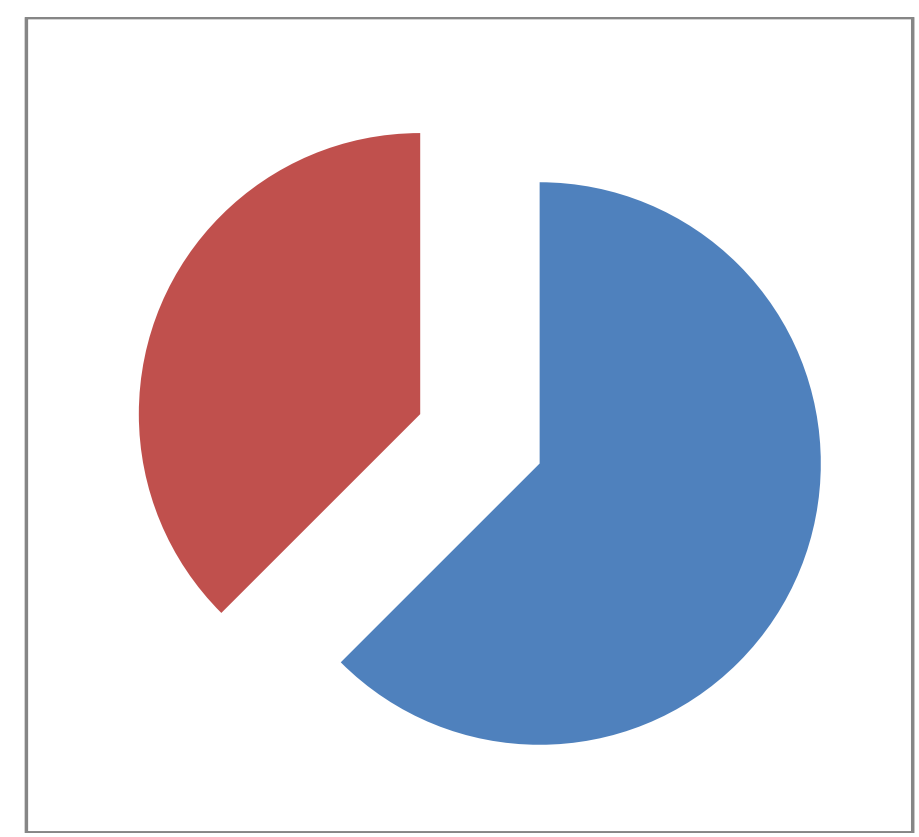

Gambar 1. Diagram Persentase Ketuntasan Siswa Kelas Eksperimen 


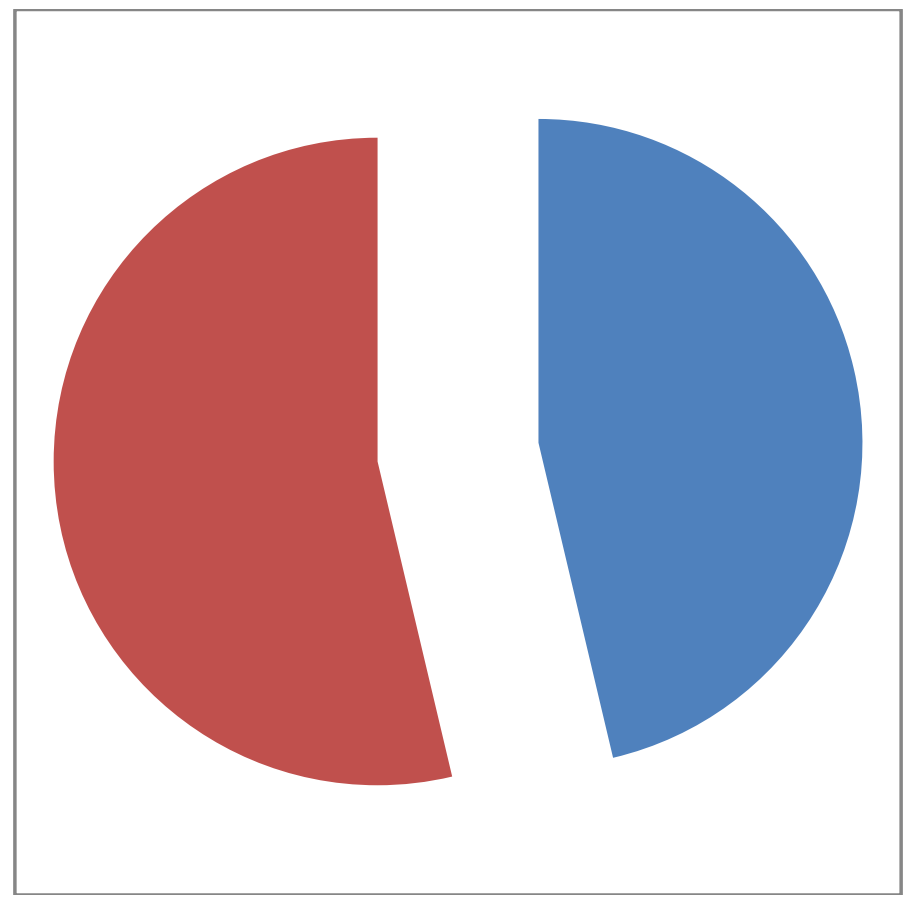

\section{Gambar 2. Diagram Persentase Ketuntasan Siswa Kelas Kontrol}

Berdasarkan Gambar 2 dan Gambar 3 di atas terlihat bahwa persentase perbandingan ketuntasan siswa pada kelas sampel (kelas eksperimen dan kelas kontrol). Hal ini, menunjukan bahwa proses pembelajaran di kelas eksperimen lebih baik dari pada kelas kontrol, dengan kata lain model pembelajaran Active Knowledge Sharing pada pembelajaran matematika di kelas V SDN 10 Sungai Sapih Kota Padang bisa membuat proses pembelajaran menjadi lebih baik.

Berdasarkan hasil uji hipotesis menggunakan uji-t, diperoleh bahwa tolak $H_{0}$ karena $t$ hitung $=2.915$ lebih besar dari $t_{\text {tabel }}=1.66$ pada taraf nyata $\alpha$ $=0,05$. Sehingga dapat disimpulkan "Hasil belajar matematika siswa yang mengikuti model pembelajaran Active Knowledge Sharing lebih baik daripada hasil belajar matematika siswa yang mengikuti pembelajaran konvensional pada kelas V SD N 10 Sungai Sapih Kota Padang tahun pelajaran 2014/2015".

Berdasarkan hasil penelitian yang dilaksanakan melalui penelitian eksperimen dengan menerapkan pembelajaran yang menggunakan model Active Knowledge Sharing pada kelas V SDN 10 Sungai Sapih Kota Padang tahun pelajaran 2014/2015. Rata-rata yang diperoleh kelas eksperimen adalah 77 , sedangkan kelas kontrol mempunyai rata-rata 67. Jadi, rata-rata pada kelas eksperimen lebih tinggi dari pada kelas kontrol. Sehingga dapat diambil kesimpulan bahwa: "Hasil belajar matematika siswa dengan penerapan model $A K S$ lebih baik dari pada hasil belajar matematika siswa dengan pembelajaran konvensional di kelas V SDN 10 Sungai Sapih Kota Padang”. 


\section{KESIMPULAN DAN SARAN}

Berdasarkan hasil penelitian yang dilaksanakan melalui penelitian eksperimen dengan menerapkan pembelajaran yang menggunakan model Active Knowledge Sharing pada kelas V SDN 10 Sungai Sapih Kota Padang tahun pelajaran 2014/2015. Rata-rata yang diperoleh kelas eksperimen adalah 77, sedangkan kelas kontrol mempunyai rata-rata 67. Jadi, rata-rata pada kelas eksperimen lebih tinggi dari pada kelas kontrol. Sehingga dapat diambil kesimpulan bahwa: "Hasil belajar matematika siswa dengan penerapan model $A K S$ lebih baik dari pada hasil belajar matematika siswa dengan pembelajaran konvensional di kelas $\mathrm{V}$ SDN 10 Sungai Sapih Kota Padang".

Berdasarkan hasil penelitian di atas, ada beberapa hal ingin disarankan antara lain: 1) Diharapkan pembelajaran matematika dengan pembelajaran $A K S$ bisa dijadikan salah satu alternatif dalam penyampaian materi pelajaran kepada siswa dalam rangka meningkatkan hasil belajar matematika siswa, 2) Hendaknya pembelajaran matematika dengan pembelajaran $A K S$ bisa dikembangkan lagi pada materi pelajaran matematika yang lain yang sesuai, 3) Penelitian ini masih terbatas pada aspek hasil belajar siswa, diharapkan ada penelitian selanjutnya yang meneliti aspek lainnya, 4) Diharapkan kepada rekan-rekan yang ingin melanjutkan penelitian ini untuk menerapkan pada pokok bahasan lain yang sesuai.

\section{UCAPAN TERIMA KASIH}

Terbitnya tulisan ini tidak terlepas dari bantuan berbagai pihak, untuk itu penulis ucapkan terima kasih yang sebesar-besarnya kepada Pihak STKIP PGRI Sumatera Barat khususnya pengelola jurnal Pelangi yang telah memberikan kesempatan kepada penulis untuk mempublikasikan artikel hasil penelitian ini di jurnal Pelangi. Selanjutnya penulis juga berterima kasih kepada para penyumbang sumber insirasi yang telah memberikan inspirasi bagi penulis untuk mengutip atau menggunakan tulisannya sebagai bahan referensi.

\section{DAFTAR RUJUKAN}

Depdikbud. 1993. Kurikulum Pendidikan Dasar. Jakarta: Depdikbud.

Erman, Suherman. 2003. Strategi Pembelajaran Matematika Kontemporer. Bandung: JICA

Hamalik, Oemar. 2008. Kurikulum dan Pembelajaran. Jakarta: Bumi Aksara.

Silberman, Melvin L. 2011. Active Learning: 101 Cara Belajar Siswa Aktif. Bandung: Nusamedia.

Sugiyono. 2009. Metode Penelitian Kuantitatif-Kualitatif dan $R$ \& $D$. Jakarta: CV. Alfabeta. 